\title{
Modelling of systemic lesion of organism for development of multitarget cellular and cytokine therapy
}

\author{
V. A. Kordium ${ }^{1,2}$, Yu. B. Chaikovsky³, D. M. Irodov ${ }^{1,2}$, M. V. Drahulian ${ }^{2}$, \\ T. P. Gulko², P. V. Buchek ${ }^{2}$, A. V. Korsak ${ }^{3}$, A. V. Neverovskiy ${ }^{3}$. \\ ${ }^{1}$ State Institute of Genetic and Regenerative Medicine, NAMS of Ukraine \\ 67, Vyshhorodska Str., Kyiv, Ukraine, 04114 \\ 2 Institute of Molecular Biology and Genetics, NAS of Ukraine \\ 150, Akademika Zabolotnoho Str., Kyiv, Ukraine, 03680 \\ ${ }^{3}$ Bogomolets National Medical University \\ 13, Shevchenko Blvd., Kyiv, Ukraine, 01601 \\ kordium@imbg.org.ua
}

In recent decades many human pathologies have taken a chronic course. Modern biology and medicine have come to conceptually new therapeutic approaches. The technologies, comprising stem cells and signaling molecules, are the most promising in this respect. They have a potential of restoring systemic lesions, which are the basis of chronicity. To develop these approaches, an adequate and realizable model is required. Here we present an attempt of elaborating such a murine model using CCl4 as an agent, causing systemic lesions.

Ke y w o r d s: CCl4, stem cells, systemic lesion, model organism, cellular and cytokine therapy.

In recent decades most human pathologies have taken a chronic course with multiple disorders. Modern biology and medicine have come to conceptually new therapeutic approaches. The technologies, comprising stem cells and signaling molecules, are the most promising in this respect. They have a potential of restoring systemic lesions, which are the basis of chronicity. To develop these approaches, an adequate and realizable model is required. The article presents the analysis of a variant of elaborating such model. Mice were selected as model animals and $\mathrm{CCl}_{4}$ was used as an agent, causing systemic lesions. The presented analysis of scientific literature demonstrates that a common opinion about $\mathrm{CCl}_{4}$ as a well- tried and tested inducer of lesions is far from being true. Each investigator modifies a scheme, but a generally accepted model of lesion due to $\mathrm{CCl}_{4}$ is the hepatic cirrhosis induced in rats. The results of studies, per- formed by the authors, allowed elaborating the methodology of modeling the systematic lesion in mice using $\mathrm{CCl}_{4}$. The scheme of this methodology is presented and the selected examples are shown to demonstrate the occurrence and character of the systemic lesion developed.

Lesions are frequent events of human life. Depending on the degree, they may be of local (injury, cut, splinter, etc.) or systemic (extensive burns, serious traumas, chronic poisoning, etc.) character, involving, although to a different degree, all the organs and functions of an organism. However, according to the meaning of the term, lesions are usually related to disorders, caused by mechanic, thermal, or poisonous impact (venom of snakes, poison of insects or plants, etc.) or highly toxic chemical substances like concentrated acids, alkali, chemical pesticides, etc. It is always harmful and dangerous,

(C) 2016 V. A. Kordium et al.; Published by the Institute of Molecular Biology and Genetics, NAS of Ukraine on behalf of Biopolymers and Cell.

This is an Open Access article distributed under the terms of the Creative Commons Attribution License (http://creativecommons.org/licenses/by/4.0/),

which permits unrestricted reuse, distribution, and reproduction in any medium, provided the original work is properly cited 
but it is clearly manifested due to the immediate development of different pathological processes. The treatment of such lesions is well worked out as standard medical procedures.

However, in reality there are damaging agents, the effect of which takes some time to declare themselves and therefore are invisible. In the air, these are vehicle motor exhausts, underoxidized combustion products from electric power stations, volatile products from chemical enterprises, airborne effluents of household chemicals, etc. In water, these are chlorine-organic compounds, sewage products not cleaned sufficiently, salts of heavy metals, etc. As for food, these are numerous "cost-efficient" substitutes, food additives, nitrates and nitrites, preservatives, dyes, sweeteners, etc. As a result all these harmful products gradually destroy organs and tissues of people, especially of those who are not very healthy, causing systemic lesions.

This chronic state may be treated though most often the current methods are not efficient enough to cure completely. Alongside the progress in science and technologies, new possibilities arise in medicine, which requires the development of the models to test the novelties prior to their use in clinical treatment. Since there are no universal models, they are designed pursuant to a given task according to the realities of our life and the cause of a definite pathology. There is a need of an adequate model to work out the treatment of chronic pathologies, caused by the lifestyle, which are typical for people, at least living in the cities. To be used as a model of the systemic lesions, it should meet a number of requirements. The first requirement is the availability of the model and financial possibility of performing the work therein, which demands the specific number of animals, their welfare, and compliance with the special rules of work with them. The next requirement is a systemic character of the model, i.e. the model agents should harm all systems of an organism though to different degree like it naturally happens. The next block of requirements is related to the model adequacy. And finally, the model should be suitable for testing the putative treatment means.
The level of modern medicine is such that it has already lost clear distinctions of its methodologies, which define it as medicine proper. Today the very names of what medicine is are different according to both their general sense and the field of activity: biomedicine, nanomedicine, non-traditional medicine, different variants of biotechnologies for humans, etc. The only permanent thing is the final object of applying this activity, i.e. a human health. However, this is only the "final" point. The roads to it are absolutely various even in their concepts. One of the ways under the most intense development (practically the change of the very paradigm of treatment) is the usage of technologies to provide self-healing of the organism. The tools used by the organism are stem cells and signaling molecules, which tell the stem cells where to go and what to do, and which tell the cells of damaged tissues what to activate, synthesize, block and so on.

At the same time signaling molecules prepare the "field of activity" in the lesion areas for the stem cells. While therein, they reconstruct, adjust the tissue and organs for the restoration on the basis of their intracellular possibilities. And all these are directed towards the acceptance of stem cells by the tissue (organs) to implement their stem functions, possibilities, and the coordination of the whole selftreatment process. Just such a complex of processes should be implemented at systemic lesions on the model in order to transfer from being treated to the technology of healing.

The analysis of current scientific data demonstrated that all these requirements to the model are met by a state, known in the literature for a long time as "cirrhosis", caused by $\mathrm{CCl}_{4}$ - carbon tetrachloride. It becomes clear while analyzing pathological processes, occurring during the action of $\mathrm{CCl}_{4}$. The first thing, requiring special attention, is the mechanism of its action. Being $\mathrm{CCl}_{4}$ only, it does not cause any lesions. Its toxic impact on the organism is initiated by the very organism [per se] [1], [2], [3]. This process starts with a cell (Fig. 1), for which $\mathrm{CCl}_{4}$ is an external agent (xenobiotic) and has to be eliminated. 
There is a complex multitarget and multilevel detoxification system for the elimination of xenobiotics and intermediate products of normal metabolism in a cell. Cytochromes P450 (CYP) are on its first line. About a hundred of them are already known. According to their activity these are enzymes, transferring different organic compounds into a form of high reaction capability. After such activation, the enzymes of the second line of protection may demolish these compounds down to the derivatives, which are not dangerous for a cell anymore and may be removed out from it and the organism. Each enzyme reacts with a specific chemical group on the xenobiotic molecule. $\mathrm{CCl}_{4}$ is mainly recognized by $\mathrm{P} 450$ cytochrome classified as 2E1(CYP2E1). Additionally, it is also metabolized by CYP2B1, CYP2B2 and, probably, CYP3A [4]. $\mathrm{CCl}_{4}$ itself is of low activity, therefore having penetrated into the cell and being the first step of a lesion, actually it has a very weak damaging effect. However, the transformations of $\mathrm{CCl}_{4}$ by its monooxidases do not lead to the desactivation process, just opposite. The first reaction, performed by CYP2E1, is the formation of trichloromethyl radical. Afterwards oxygen may come into action and transfer a trichloromethyl radical into a considerably into a more reactive trichloromethyl peroxy radical with a mostly high damaging potential. Additionally, the third radical is being formed chlorine $(\mathrm{Cl} \cdot)$ [5]. These radicals attack "everything", but first of all the polyunsaturated fatty acids of membrane phospholipids, which are most susceptible to their impact. The damage of phospholipids leads to the local destruction of cell membranes, both cytoplasmic and inner, which results in the disorganization of membrane-bound processes. This is the second, clearly evident level of a lesion, caused by the secondary toxic effect of free radicals, formed from the primary agent $-\mathrm{CCl}_{4}$.

The disruption of membranes leads to a double effect. The enzymes (oxidases, peroxidases, hydrolases, etc.), which form the highly reactive groups in molecules inside the cell, are released from the intracellular compartments, named "microsomes", such as lysosomes, peroxisomes, endosomes,etc. More- overe, the enzymes, degrading macromolecules, nucleases and proteases, are also released from the microsomes. At the same time because of the disruptions of the cytoplasmic membrane $\mathrm{Ca}^{2+}$ enters into the cell from outside without any control. It activates $\mathrm{Ca}^{2+}$-dependent proteases, phosphatases, endonucleases, etc., again in an uncontrolled way. All this leads to the continuous formation of various high-reactive compounds, which chaotically destroy the macromolecules as such and cellular structures, formed by them. The destruction of membranes by free radicals, formed out of $\mathrm{CCl}_{4}$, leads to the formation of the third degree of a lesion, conditioned by the tertiary toxic effect due to the products, formed by the enzymes released from microsomes.

However, there is the powerful defense-in-depth in the cell from both reactive oxygen intermediates and lesions, caused by them. The highest effect is achieved by the glutathione system for the inactivation of reactive intermediates of any nature and origin and for the reparation -the restoration of the genome from lesions. It gets activated and decrease the toxic effect at all the levels of lesions. However, $\mathrm{CCl}_{4}$ is continuously coming in. Therefore, the lesion factors are formed persistently in large amounts at all levels and the resulted damage is growing that leads to the exhaustion of the system of defense and restoration. Long-term and excessive stimulation always leads to the exhaustion of repair processes. As the stimulation is associated with the overpressure it is useful only for a short while. As for the constant uptake of $\mathrm{CCl}_{4}$, the stimulation effect is permanent and the overpressure ends with a drop in the activity of the defensive and restoring systems. Under physiological conditions these systems mainly exist in the cell for the intracellular provision of the normal metabolism. The high-reactive intermediate metabolites are formed practically at all the stages and cycles of the metabolism, except for the final ones. The part of these products leaves the active centres of enzymes due to some accidental stochastic deviations. These high-reactive intermediate products actually are the main trouble for the systems of defense and res- 


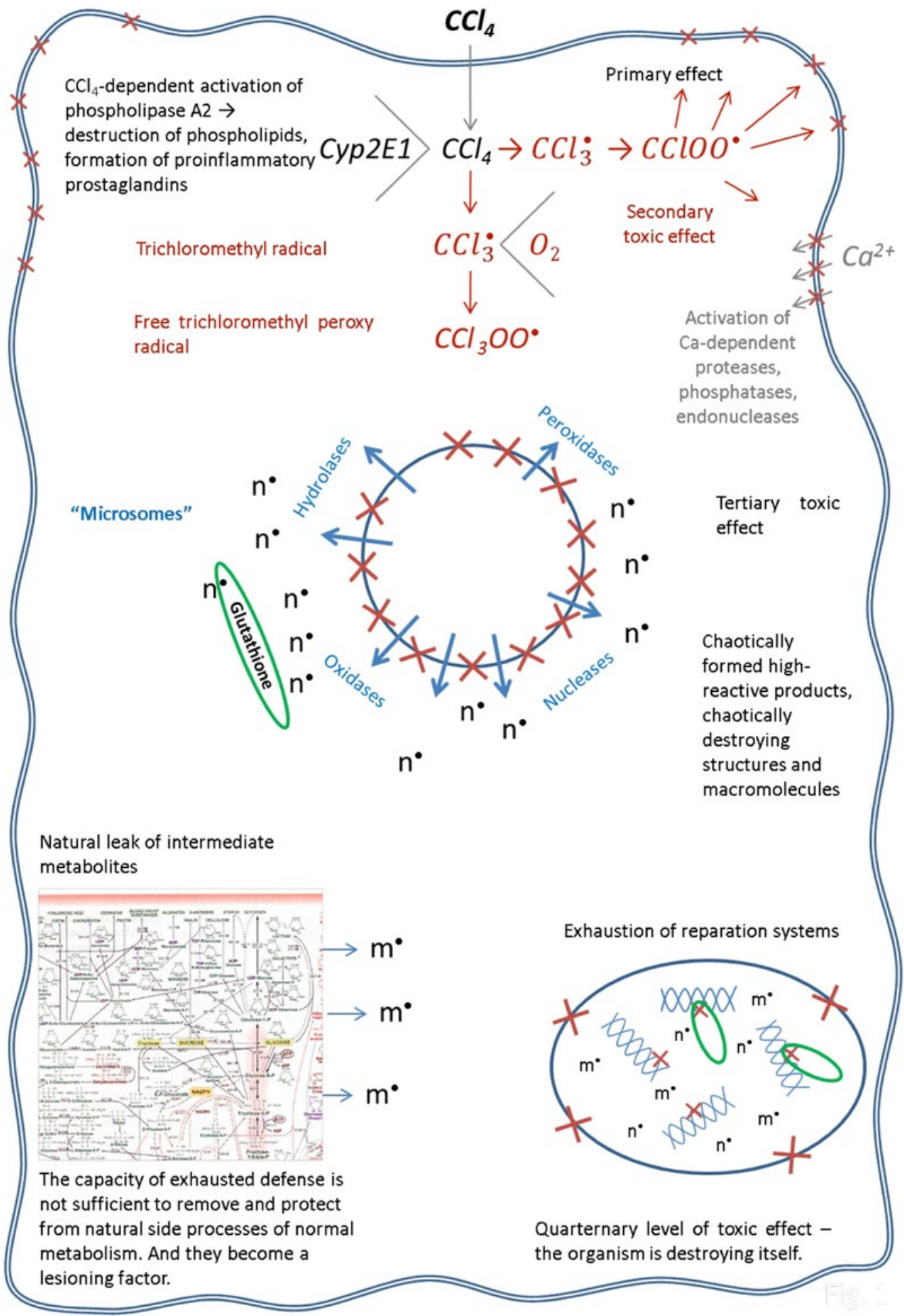

Fig. 1. The scheme of events under the impact of $\mathrm{CCl}_{4}$ on the cell 
toration. Many of these potentially dangerous products are formed in the cell [6] and with all the perfection of metabolism, at norm their number is considerably exceeding the harmful products entering into the cells from outside. The exhaustion of the defense and restoration systems, which occurs due to eliminating the products of three levels of lesions under the effect of $\mathrm{CCl}_{4}$, leads to the situation when the efflux of high-reactive intermediate products of normal metabolism becomes uncontrolled, and they form the fourth, probably the most powerful, level of the lesions. Having been deprived of the required level of the activity of defense systems, the organism destroys itself. There comes the finale - the cells perish.

This is an authentic cellular level, but the organism is too complex system to have something "in its pure form". Long before the terminal event - the death of cells, the whole organism is getting involved into the pathological process after the $\mathrm{CCl}_{4}$ introduction. The developing systemic lesion is the consequence of dependent and related interactions. The first, mechanism of these interactions operates at the cellular level, described above, and in one way or another in all the cells of the organism. The second one is related to the organism functioning as a system. The organism as a system has been studied and described globally including the specific metabolic chains, signaling cascades, etc. The detailed schemes are given in numerous publications and the study is still in progress. However, the spatial and temporal dynamics of the cumulative process is absolutely unclear. One of its elements belongs to the main mechanisms, defining the systematicity of the lesion. It is related to the system that may be called "housekeeping" by analogy with the intracellular processes. Speaking about the organism, this term may be used regarding the processes, occurring only and directly for the purpose of a total organism functioning. The term "homeostasis" is the closest to it, but by its origin and use it does not include the intracellular processes, which actually ensure homeostasis, whereas "housekeeping" envisages everything as a whole at all levels, from the molecular one to the central ner- vous system controlling actually all events inside the organism. At the organism level the "housekeeping" is a two-sites process. It means providing all the cells with food substances as the first stage of the subsequent metabolism and simultaneous removing of the waste, extracted by the cells, - the products of metabolism which the cell cannot destroy and reutilize, but the constant accumulation of which might lead to the severe dysfunctions and death.

This provision is organized in such a quasi "simple" way that it is still impossible to comprehend it at the level of primary mechanisms. These "simplicity" and incomprehensibility are related to the fact that both nutrients for cells and wastes from the latter are evenly distributed in the general system, which is the blood circulation. Everything from the intercellular space, all the wastes of all the cells of the organism enter blood. The inputs of each of cells are constantly mixed, combined and finally form lymph which continuously enters the At the same time the alimentary substances which bypassed intestinal cells and liver go into the blood flow as well and became nutrients for all (!) the cells of the organism. This mixture of wastes and nutrients is permanently circulating in the whole organism.

De facto, the blood circulatory system is both a "sewage system" of the organism and its "life artery" in the same structure simultaneously and jointly. Thus, the blood is an unprecedented dynamic mixture of essential vital products - oxygen, nutrients of the whole spectrum, water and at the same time all the kinds of wastes of cellular activity, molecular trash, thrown out of the cells, residues of decaying dead cells, harmful gases and volatile substances. All this is dissolved in the aqueous phase of blood and co-exists concurrently in the form of allcontaining mixture under very complex dynamics.

At the same time this mixture gets purified (in a small percentage for each cycle of "priming") in liver mainly. There is only a general idea of how liver cells distinguish the whole spectrum of "wastes" which should be removed by elimination from the whole mixture. There is over a dozen known scavenger receptors, but the exact details about the way of 
selecting the items for detoxification from the whole composition are unknown. The study of the consumption and selection is still conducted on the individual products only, and all the rest is mere extrapolation and generalization. At the same time the whole spectrum of nutrients, from microelements to complex molecules of "irreplaceable" components like vitamins, penetrate selectively via the walls of capillaries, getting distributed among all the cells of tissues to maintain the housekeeping of the organism (Fig. 2). The cells select nutrients, coming out of the capillaries, from their intercellular space, from the products they have thrown into it as wastes. In their turn these wastes gradually migrate to the lymphatic vessels and enter into the blood .

This process goes on during the whole life at norm (i.e. at the most favorable conditions). When $\mathrm{CCl}_{4}$ enters the organism, the liver, being the central organ of detoxification - the "purification plant" of the organism, takes mostly upon itself its elimination. Similar to the detoxification of all the wastes, coming into blood from all the cells at norm, this is mainly performed by the liver cells. But under the effect of $\mathrm{CCl}_{4}$ the above described cascades of lesions start and develop and hepatocytes are the most damaged ones. The efficiency of the purification function of the liver decreases. The level of constantly incoming $\mathrm{CCl}_{4}$ is increasing in blood along with the level of insufficiently purified wastes. Cytochromes P450 are present in all cells of the organism. They are required for the detoxification of multiple high-reactive products of the normal metabolism. $\mathrm{CCl}_{4}$, incoming into the organism, is metabolized in all the cells. With the growth of its content the damaging impact on the cells, firstly on hepatocytes, is increasing as well as the destruction due to the accumulation of other wastes of organism.

The organism starts destroying itself at many levels. Inside a cell it occurs due to the destruction levels initiated by $\mathrm{CCl}_{4}$. The systemic destruction occurs due to the increase in $\mathrm{CCl}_{4}$ concentration in all the cells, the decrease in its detoxification by the hepatocytes, which are being destroyed, and via the blood flow as a result of the increase in the amount of all the kinds of wastes caused by the same drop in the activity of hepatocytes. The situation is complicated with the development of the systemic inflammation owing to the activation of pro-inflammatory cytokines, the increase in the level of pro-inflammatory prostaglandins and so on. This is how the pro-

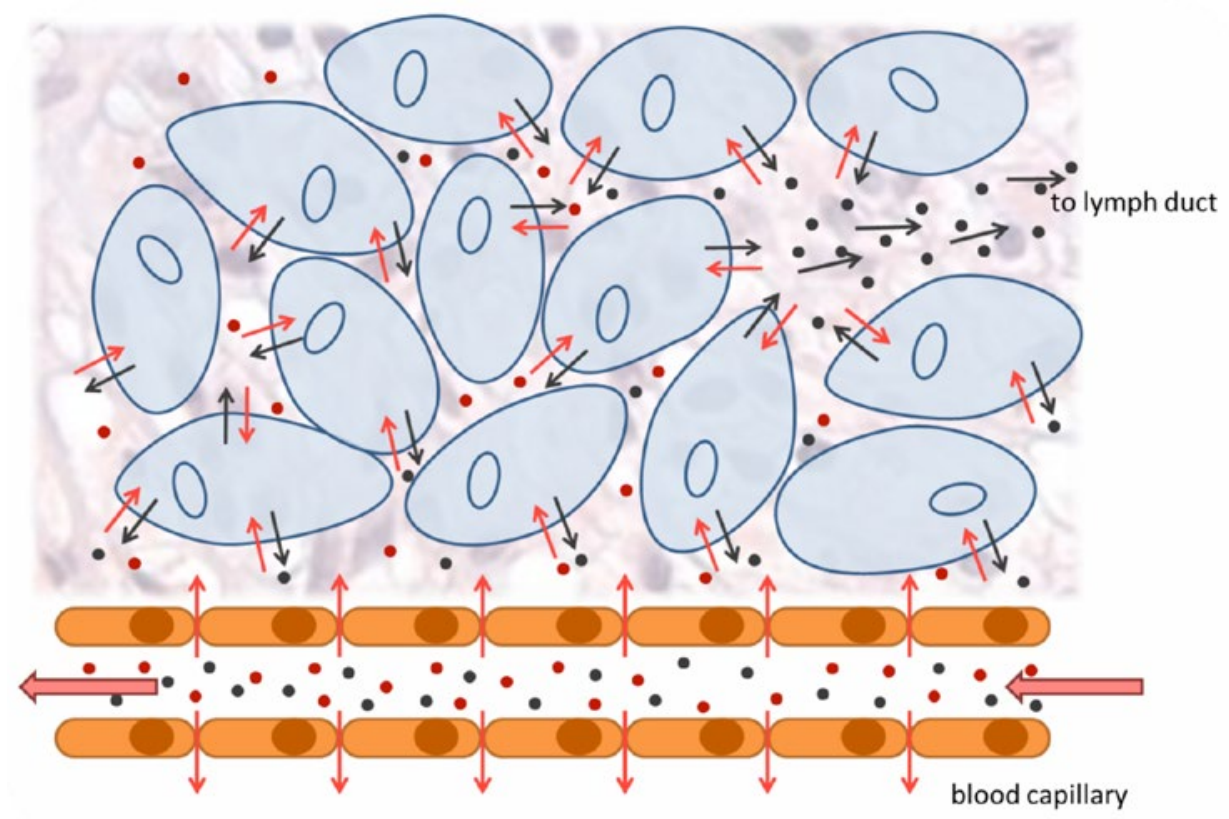

Fig. 2. The remarkable phenomenon of the organism "housekeeping" - the shared circulatory system to deliver nutrients and to remove metabolic wastes. 
cess of systemic lesion is advancing. In itself, the degree of susceptibility, sensibility and responsiveness is not the same for different tissues and different organs, therefore, the lesions will be dissimilar in them and expressed to a different degree. It happens always that with any systemic lesion of an organism all systems are injured, but to a varied degree. In this respect the model under description is rather adequate to the reality of life. The chosen model has unique "universal advantage" which is related to the fact that the lesions are not directly caused by $\mathrm{CCl}_{4}$ itself. The lesions of cells, tissues, organs are caused by the damaging agents of the cascades, which are realized for all the systemic lesions, usually occurring in life.

Different researchers have extensively used $\mathrm{CCl}_{4}$ in this respect as a model of lesion caused by toxic xenobiotics [7], [8]. It is related to the fact that xenobiotics - dyes, thickening agents, preservatives, flavours, etc., present in our food in a vast amount, as well as unnatural compounds in water and air, usually exploit the same mechanism of their effect. Similar to $\mathrm{CCl}_{4}$, they induce the cascades of highly active products, destroying cells, under the impact of different members of the cytochromes P450 subpopulation. And it is easy to influence a degree of model lesion, using $\mathrm{CCl}_{4}$. It requires only selecting a proper scheme of the experiment.

There are a great number of scientific works, dedicated to the toxic effects of $\mathrm{CCl}_{4}$. They have been performed on different objects - from the research on separate processes in vitro to the extensive experiments on animals. This rather multifold field of investigations of a long history initiated almost a universal belief that "everything is already known here". It is true that the part related to the sophisticated mechanisms of the lesion emergence has been studied rather in details though almost exclusively in vitro. There is no doubt that $\mathrm{CCl}_{4}$ is harmful, but already at the level of model simulation of this effect in real time of chronic poisoning, everything turned out to be quite different from the common beliefs.

In summary the situation in this field may be presented as a quote from the review of the representa- tive of the Office of Pesticide Programs, U.S. Environmental Protection Agency, Washington D.C., USA:" A large number of studies ( $\square 50)$ have been conducted in mammalian systems after the administration of carbon tetrachloride in vivo Most of these have yielded negative results, with the notable exceptions indicated below. Negative results were seen in almost all studies in which genotoxic effects were evaluated in non-target (i.e, non-hepatic) tissues "[3].

It means that despite the attractiveness and theoretical substantiation even the liver lesion was not always achieved, let alone the systemic lesion of the organism. The analysis of the works in this field shows just an endless variety of experimental schemes, conducted and described in the literature.

The most demonstrative in this respect are the recommendations how to achieve the experimental cirrhosis. Some of them are so meticulous as to indicate every detail, including the name of the company, producing the syringes, which are to be used in such experiments [9]. As for the other works, the authors use everything in a different way. It seems to happen only in case if the recommended approaches work out only for their authors and in their specific settings, although they are recommended as universal ones. For instance, the review of Marques et al. (2012) [10] presents the table with a list of experiments on the toxic effect of $\mathrm{CCl}_{4}$ in rats (during 2008-2009), which shows that the experiments were conducted in the time range from $36 \mathrm{~h}$ to 18 weeks, sometimes even without any indication of the time period. As for the schemes and doses, they were various. As strange as this situation seems to be, it turns out that no common, reliable, practically reproducible and standardized procedure was obtained to yield reliable results in extensive long-term studies of the toxic effect of $\mathrm{CCl}_{4}$. It is noteworthy that out of all the possible lesions, caused by $\mathrm{CCl}_{4}$, the majority of works studied only the events in the liver. It is explained by the fact that they emanated from the fact that $\mathrm{CCl}_{4}$ causes cirrhosis and thus is important mainly (or merely) just as a model of hepatic cirrhosis in humans. Soon it became evident that, as cir- 
rhosis, this model is only the development of liver lesion in rats. And in the experiments conducted in order to reproduce the expected results this process was studied in fine detail. Mice do not develop cirrhosis in the form, described for humans, under the effect of $\mathrm{CCl}_{4}$ [9]. It gives some grounds, it opens the door for their use to work out a model of systemic lesion of the whole organism. This idea is so alluring that there is a constant research in this direction, although the publications of successful results are quite rare. Rather successful example may be found in the publication of Das et al. (2014) [11], which describes the lesion of both liver and lungs. However, in this study the liver lesions in mice were induced not by pure $\mathrm{CCl}_{4}$, but by a unique complex - with preliminary application of phenobarbital for a week and then during the whole experiment (for 12 weeks). It stimulates the activity of cytochromes P450 and thus enhances the effect of $\mathrm{CCl}_{4}$. The authors state the specificity of the results obtained because of the fact that peroxidized lipids were not found in the lungs contrary to the liver. At the same time peroxidized lipids were found in the lungs in the experiments on rats without any phenobarbital. The authors came to the conclusion that as the lung lesion under the effect of $\mathrm{CCl}_{4}$ in their experiments was not accompanied with the cascade of peroxidation of lipids, there is a different mechanism of this lesion. However, the whole process is changed, since the central point is removed - the destruction of membranes - from the system of lesion emergence effects. It may be due to the use of phenobarbital. However, the very fact of the lesion of both liver and lungs is very illustrative, although the main criteria in the cited work were hypertension and changes in vessels. There is detailed communication about the terms and effects of the injection of $\mathrm{CCl}_{4}$, but it states that regardless of the effect and scheme there was self-restoration [9]. There are descriptions of lesions of kidneys [12] and other organs. Knock-out mice were used as models as well [13]. However, all this research was directed to solve some specific tasks.

The above analysis of the scientific data was used by us to plan the experiments for obtaining a model of systemic lesion in mice.

The series of experiments was aimed at working out the systemic lesion of different stages of development. It was necessary to find the stages of the process, when both self-restoration and return to the relative norm are still possible, or when it becomes
$A$

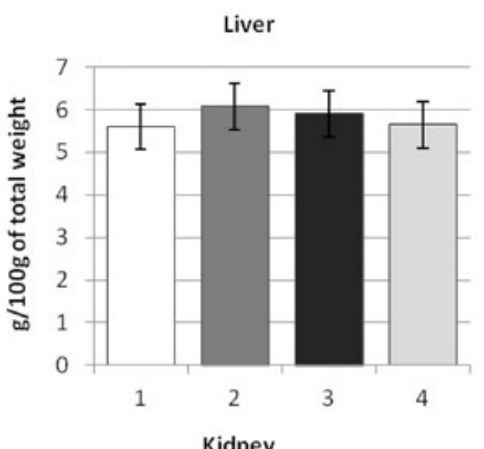

D

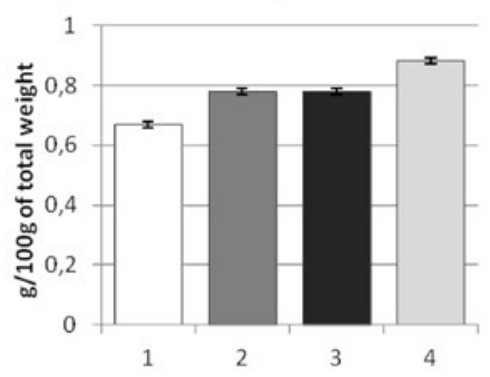

B

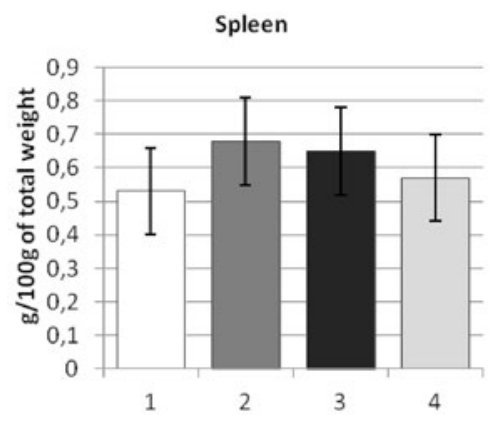

Fig. 3. The change in the weight of organs of experimental animals compared to average normal weight of the corresponding organs of healthy animals in the basic 10-13-week-long experiment. $A$ - control (healthy animals), $B$ - mice after 10-weeklong injections of $\mathrm{CCl}_{4}, C$ - mice after added 3-week-long of $\mathrm{CCl}_{4}$ injections, $D$ - mice after 3-week-long self-restoration following 10 -week-long injections of $\mathrm{CCl}_{4}$. 


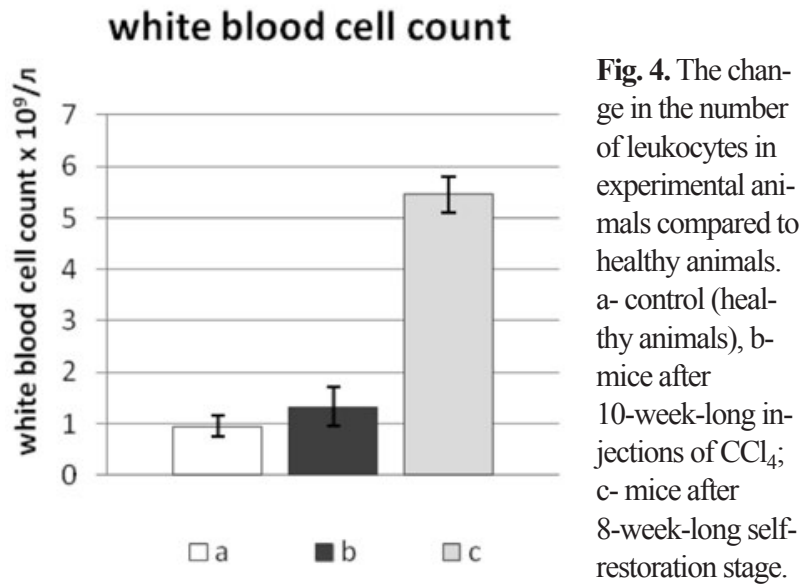

irreversible. First of all, systemic lesions trigger the implementation of genetically predetermined "hereditary predispositions". The vascular and oncology predispositions are most common for humans, determining two main reasons of mortality. The vascular lesions after the injection of $\mathrm{CCl}_{4}$ were previously described in literature [11]. As for the oncology predispositions, they were excluded in the previous studies due to the use of the mice without oncology predisposition. Therefore, to approximate the model to the "original", a highly cancerous line of mice, ICR, was used in the experiment. A wide range of $\mathrm{CCl}_{4}$ doses, the frequencies of its injection and experiment duration were studied to search for the optimal scheme of obtaining the systemic lesion. There were over ten independent experiments. The most effective dose of $\mathrm{CCl}_{4}$ was $30 \%$ solution with olive oil in $1.5 \mu \mathrm{l}$ per $1 \mathrm{~g}$ of the animal bodyweight, twice a week, abdominally, in the course of 8-14 weeks of constant unceasing injections. After that some animals were removed from the experiment, and some were left for 3-8 weeks longer to control their self-restoration. The higher the degree of the lesion was, the broader range of different indices was observed at the self-restoration stage, which demonstrated considerable differences in their sensitivity regarding carbon tetrachloride. (Fig. 3)

The analysis of white blood cells demonstrates that the pathological process, registered by the number of leukocytes, is going on even when carbon tetrachloride is no longer introduced. The process of lesion of organs may be brought up to any level via either continuous use of $\mathrm{CCl}_{4}$ or the termination of this procedure. However, only 10-12 weeks later the process of systemic lesion develops up to its critical stage - irreversibility (Fig. 4).

A noteworthy moment is the fact that $\mathrm{CCl}_{4}$ inhibits the defensive function of the organism, blocking the increase in the number of leukocytes (Fig. 4, a). It is reflected in the fact that while introducing $\mathrm{CCl}_{4}$ the number of leukocytes does not increase compared to the control (healthy animals). But when
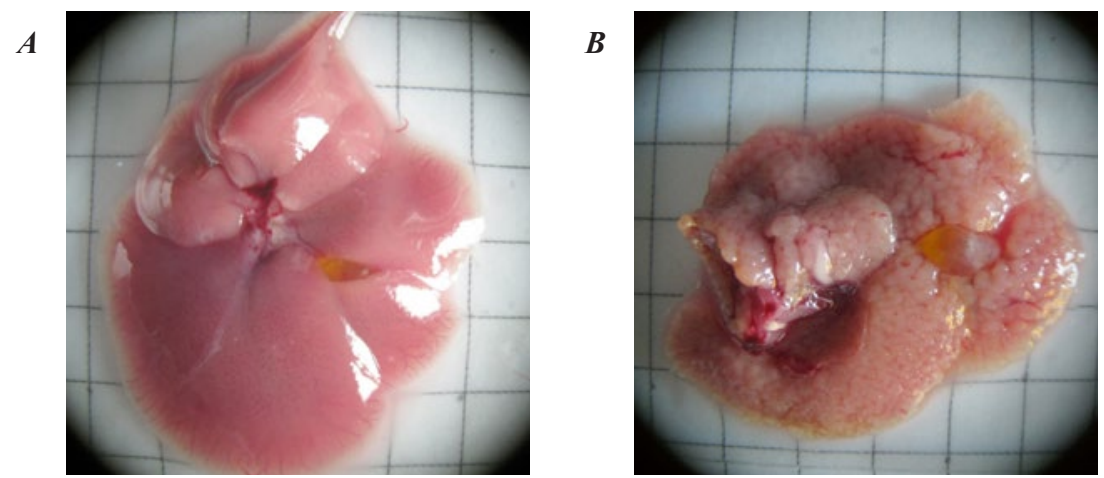

Fig. 5. General view of the liver. $A$ - control mouse, $B$ - mouse after 12 weeks of CCl4 injections. There are signs of granular and fatty degeneration of hepatocytes, liver is evenly colored, areas with severe degenerative changes are gray-whitish or grayishyellow color, many areas of dry necrosis, liver blood vessels are dilated, full of blood (acute venous congestion).

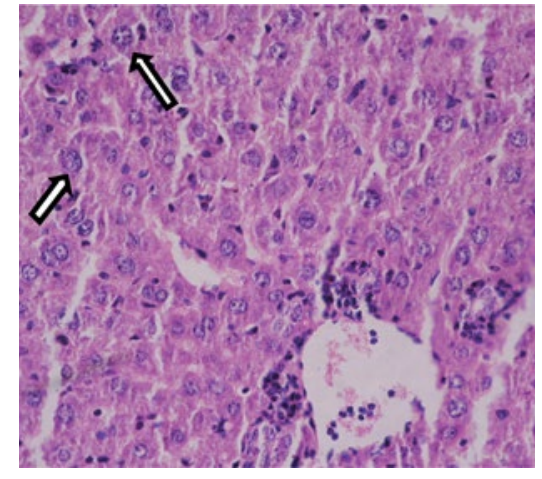

Fig. 6. Microphotograph of the murine liver after 12-week-long injection of $\mathrm{CCl}_{4}$. Arrows indicate enlarged nuclei. Haematoxylin-eosin staining. Ob. 40, Oc. 10. (Zoom x400) 
A

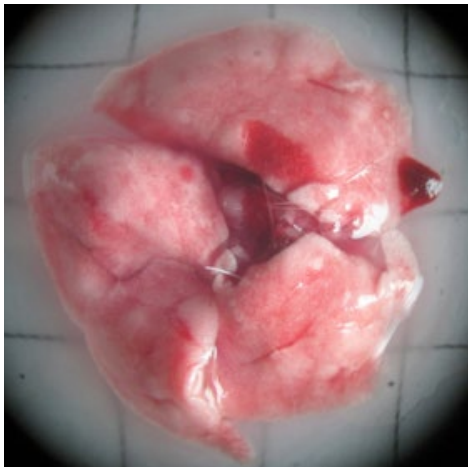

$\boldsymbol{B}$

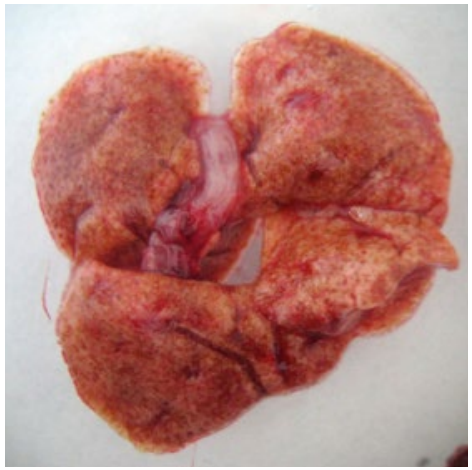

Fig. 7. General view of the lungs. $A-$ control mouse, $B$ - mouse after 12 weeks of $\mathrm{CCl} 4$ injections.
$\mathrm{CCl}_{4}$ is no longer effective, the restoring defensive reaction of the organism leads to a rapid increase in the number of white blood cells (Fig. 4, c).

$\boldsymbol{A}$
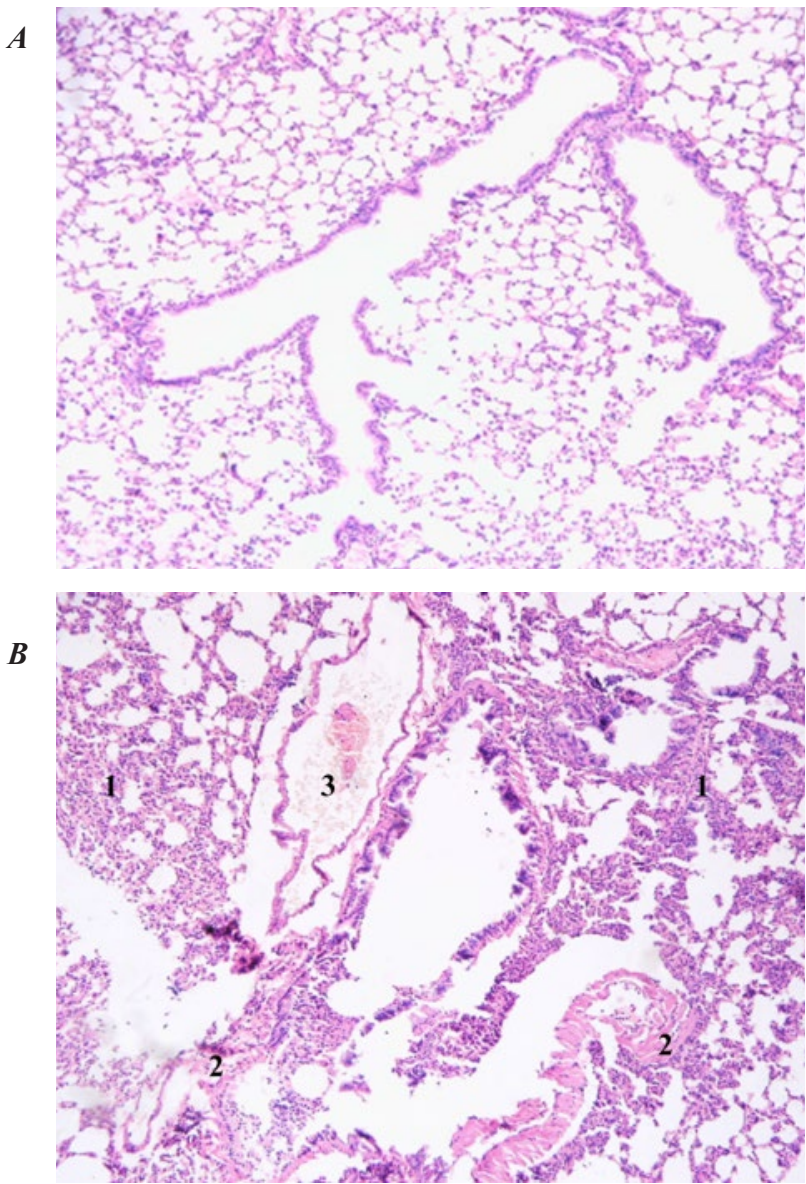

Fig. 8. Histological investigation of the normal (A) and the damaged (B) lungs. Haematoxylin-eosin staining. Zoom x100.
Liver is damaged the most (Fig. 5). It seems to be absolutely obvious due to the hepatic function and the above described mechanism of $\mathrm{CCl}_{4}$ action. The same was noted by other researchers.

$\boldsymbol{A}$

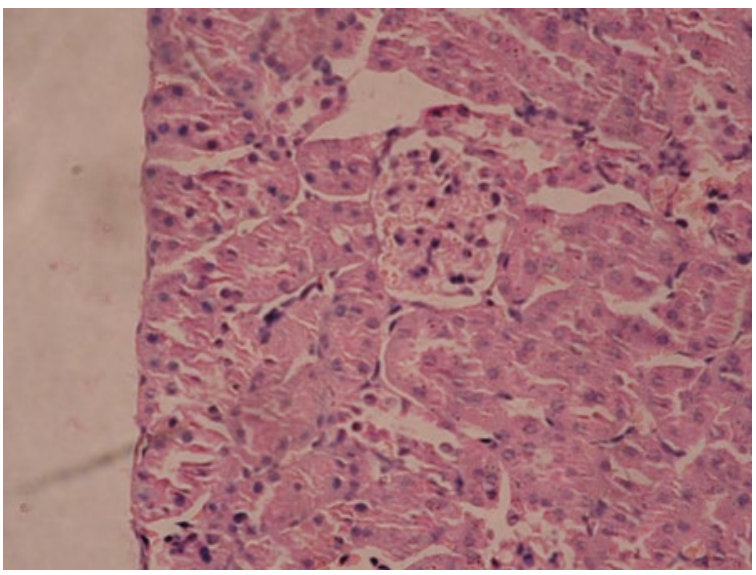

$\boldsymbol{B}$

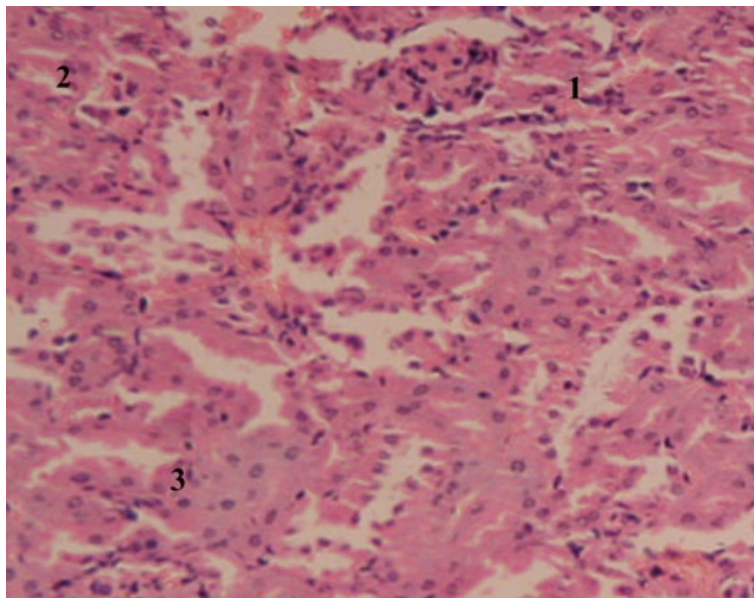

Fig. 9. The histological study of the normal (A) and the damaged (B) renal parenchyma. Haematoxylin-eosin staining. Zoom x200 
The histological picture of the liver is characterized by obvious changes in the general structure with the micronodular reconstruction of the tissue and insignificantly expressed fibrotic changes in stroma such as increased number of collagen fibers in the zone of portal areas. There is disassembling of hepatic tubules within the alteration zones, hepatocytes are enlarged due to edema and lose their polygonal form. The cytoplasm of hepatocytes is inconsiderably lighter due to small vacuoles, mainly in the central areas of liver acini which testifies to moderately expressed hydropic degeneration and hepatic steatosis. The nuclei of liver cells are enlarged due to edema, they look lighter, the total number of nuclei is reduced. Central veins and triad vessels are varicose and full-blooded. The sinuses between tubules are irregular, with zones of narrowing and dilatation, there is hyperplasia of Kuffper cells. The expressed diffuse disseminated segmented leukocytic infiltration of hepatic parenchyma is found (Fig. 6).

The lungs are damaged almost as much although somewhat later (Fig. 7). There are considerable changes in the spleen. Closer to the terminal stage there is lesion of pancreas.

The normal lung parenchyma is characterized by alveolar histoarchitectonics, the acinus structure is preserved. There is sufficient visualizable alveoli lumen, interalveolar septa are not enlarged. Alveolocytes of types I and II are clearly differentiated. The lumen of terminal bronchioles is preserved, the epithelium, lining them, and Clara cells are clearly determined. The blood content of vessels is even, with no observed dilatation or narrowing.

The $\mathrm{CCl}_{4}$ damaged lung parenchyma is characterized by the loss of normal alveolar histoarchitectonics with degenerative changes in alveolar septi and bronchioles. There is a decrease in alveoli with the narrowing of their lumen, interalveolar septi are enlarged via cellular infiltration and sclerosis (Fig. 8-1). Alveolocytes of type I and II are not clearly differentiated. The epithelium of terminal bronchioles is disorganized, with places of ruptures, Clara cells are of irregular form, their number is reduced. The lumen of terminal bronchioles is reduced. There are areas of aggregation of fibroblasts with enhanced collagen formation along the whole tissue of the lung (Fig. 8-2). The blood content of vessels is not even, there are aggregates of blood corpuscles in the lumen of blood vessels (Fig. 8-3). There is diffuse segmented leukocytic infiltration.

Normal renal parenchyma is presented with renal cortex and medullary substance. The structure of renal corpuscles (glomeruli) is preserved. Bowmen's space is not dilated. The epithelium of renal tubules is clearly visualized, the nuclei are preserved. The lumen of renal tubules is preserved. There is inconsiderable interstitial edema. The blood content of vessels is even, with no observed areas of dilatation or narrowing.

The $\mathrm{CCl}_{4}$ damages renal parenchyma is characterized by alterative-degenerative changes in both renal cortex and medullary substance. There is an alternation of areas of capillary plethora with erythrocytic stases and areas of low blood content with obliteration of vascular lumen, the expressed interstitial edema with areas of sclerosis and fibrosis (Fig. 9-1), diffuse leukocytic infiltration of renal cortex and medullary substance. There is predominant atrophy of renal glomeruli (Fig. 9-2) with areas of dilated Bowmen's space and rare zones of necrosis and sclerosis of glomeruli. The epithelium of renal tubules is in the state of dystrophy and necrosis (Fig. 9-3), the boundaries between epitheliocytes are not defined, the nuclei are reduced in size. The lumen of renal tubules is dilated, in some places it is filled with detached epitheliocytes.

There are no observed significant disorders in the heart at all. However, this picture is "static". As for individual susceptibility and the character of lesions of organs, it may differ considerably for different animals.

Regardless of all the significance of usual and common methods of estimating the state of experimental animals (ALT, AST, the weight of organs and their statistical processing to obtain reliable average values, etc.), they do not provide for the adequate picture, as the averaging in terms of in- 
dividual susceptibility does not correspond to the reality.

At the first glance this individuality of reaction may be quite strange for different mice of the same line. However, the analysis of the linearity of animals demonstrates that it cannot be any other way. The linearity of animals and the corresponding selection for linearity are performed by a limited number of markers. These are genetic and thus phenotypic identities by the features, which characterize the line as well as periodic control tests in the identity of animals of this line according to the acceptability of transplanted skin of one animal for another one. In addition, the very reproduction is inside the line, which prevents including the foreign genetic material and promotes unification of the population genome. However, as for genetically determined processes, involved in the cascades of systemic lesion development, this selection for linearity was not carried out. At the same time it involves a considerable number of individual molecular, biochemical and complex systemic processes. These processes are determined by both individual and interrelated events, wherein the products of a considerable number of genes from the whole genome take part. This is evident in the cascades of cell destruction development in Fig. 1. The subsequent systemic lesion of the whole organism is even more complicated and multifold.

The variety of individual features may be different in different lines, but it is inevitable as a phenomenon. Still, it is not discussed in the literature. It may be explained by the fact that firstly, the main works in $\mathrm{CCl}_{4}$ effect were carried out using rats whereas there were rare ones with mice. Liver was the object of research in almost all of them. As cirrhosis in mice is not induced by carbon tetrachloride, there have been no studies, going beyond the statement of this fact and mere estimation of liver lesions, resulting in the death of the animals. There are some works on the mechanism of $\mathrm{CCl}_{4}$ action, but they have been limited to early stages.

Independent settings of the experiments also differ in absolute values. It may be assumed that this is related to the fact that animals differ in their physiological, biochemical and other features in different seasons and with sharp weather changes. As the reproduction cycles of mice are rather short, young animals of different broods will not be identical in physiological quantitative indices. The analyses of the organs of healthy animals confirm this assumption. The absence of identity of animals from time-wise different broods cannot but impact the absolute values of indices in the experimental variants. But with all these differences, the general direction of the lesion processes, caused by $\mathrm{CCl}_{4}$, has the same character inthe experimental groups.

When analyzing the main results of the experiments performed, the following conclusions may be formulated

- The elaborated scheme of developing the systemic lesion in mice due to the long-term injection of carbon tetrachloride provides the wellreproducible results according to the general direction of the process. However, their reproducibility requires a precise fulfillment of the experimental scheme. It should be taken into consideration that mice of different lines may differ in their susceptibility to $\mathrm{CCl}_{4}$. There cannot be a single quantity-wise scheme (dose, interval, cycle) for all the lines. Only some basic format may be provided and it is reasonable to check previously the susceptibility of the selected line. This could be achieved using the suggested scheme with the variants of a higher and a lower dose of $\mathrm{CCl}_{4}$ as a basis while the entire duration of introducing $\mathrm{CCl}_{4}$ should correspond to the specific task.

- There is some nonuniformity in the response to the lesion emergence, induced by $\mathrm{CCl}_{4}$, even among linear animals. This may lead to considerable differences in the absolute values of indices for the lesions of different organs of individual animals in experimental groups. This fact should be taken into consideration. However, regardless of such individual differences, the statistical direction and character of 
the systemic lesion, induced by $\mathrm{CCl}_{4}$, are preserved.

- The absence of identity of absolute values of systemic lesion indices in different independent experiments requires using the data of each specific experiment for the comparative analysis of the effects. It is possible to conduct the quantitative analysis of the results only among the groups inside the specific setting. The quantitative comparison of different independent experiments may result in inaccurate conclusions.

- If the lesion has not developed in proper time (small doses, insufficient duration, rare injections), the individual differences may bring to the results, which lead to misrepresentation of the whole picture of lesions and, therefore, to the inadequate conclusions.

- Due to the effect of $\mathrm{CCl}_{4}$, the animals with the genetic predisposition to tumor formation develop tumors at the terminal stage of the lesion. However, the tumors are rarely registered at the intermediate stages. As the experiment involved the young mice (and the possibility of carcinogenesis development is usually realized by the age of one year), it allows the assumption that the availability of genetic predisposition does not have a considerable impact on its realization in the case of systemic lesion with xenobiotics, at least within the time range of common observations.

\section{REFERENCES}

1. Recknagel RO, Glende EA Jr, DolakJA, Waller RL. Mechanisms of carbon tetrachloride toxicity. Pharmacol Ther. 1989;43(1):139-54.

2. McGregor D, Lang M. Carbon tetrachloride: genetic effects and other modes of action. Mutat Res. 1996;366(3):181-95.

3. Manibusan MK, Odin M, Eastmond DA. Postulated carbon tetrachloride mode of action: a review. J Environ Sci Health C Environ Carcinog Ecotoxicol Rev. 2007;25(3):185-209.

4. Weber LW, Boll M, Stampfl A. Hepatotoxicity and mechanism of action of haloalkanes: carbon tetrachloride as a toxicological model. Crit Rev Toxicol. 2003;33(2):105-36.

5. Brattin WJ, Glende EA Jr, Recknagel RO. Pathological mechanisms in carbon tetrachloride hepatotoxicity. J Free Radic Biol Med. 1985;1(1):27-38.
6. Kordium VA, Shuvalova NS. The concept of «origin»problem definition and attempt of analysis. Biopolym Cell. 2013; 29(5):428-40.

7. Basu $S$. Carbon tetrachloride-induced lipid peroxidation: eicosanoid formation and their regulation by antioxidant nutrients. Toxicology. 2003;189(1-2):113-27.

8. Geerts AM, Vanheule E, Praet M, Van Vlierberghe H, De Vos M, Colle I. Comparison of three research models of portal hypertension in mice: macroscopic, histological and portal pressure evaluation. Int J Exp Pathol. 2008;89(4):251-63.

9. Constandinou C, Henderson N, Iredale JP. Modeling liver fibrosis in rodents. Methods Mol Med. 2005;117:237-50.

10. Marques TG, Chaib E, da Fonseca JH, Lourenço AC, Silva FD, Ribeiro MA Jr, Galvão FH, D'Albuquerque LA. Review of experimental models for inducing hepatic cirrhosis by bile duct ligation and carbon tetrachloride injection. Acta Cir Bras. 2012;27(8):589-94.

11. Das M, Boerma M, Goree JR, Lavoie EG, Fausther M, Gubrij IB, Pangle AK, Johnson LG, Dranoff JA. Pathological changes in pulmonary circulation in carbon tetrachloride (CC14)-induced cirrhotic mice. PLoSOne. 2014;9(4):e96043.

12. Ganie SA, Haq E, Hamid A, Qurishi Y, Mahmood Z, Zargar BA, Masood A, Zargar MA. Carbon tetrachloride induced kidney and lung tissue damages and antioxidant activities of the aqueous rhizome extract of Podophyllum hexandrum. BMC Complement Altern Med. 2011;11:17.

13. Das M, Fessel J, Tang H, West J. A process-based review of mouse models of pulmonary hypertension. Pulm Circ. 2012;2(4):415-33.

Модель системного ураження організму для розробки багатоцільовий клітинно-цитокиновой терапії.

В. А. Кордюм, Ю. Б.Чайковский, Д. М. Іродов, М. В. Драгулян, Т. П. Гулько, П. В. Бучек, А. В. Корсак, А. В. Неверовський.

В останні десятиліття основні патології людини прийняли, у своїй більшості, хронічний характер з множинними порушеннями. Сьогодні біологія і медицина вийшли на принципово нові можливості лікування. Найбільш перспективними в цьому плані $є$ технології, що використовують стовбурові клітини і сигнальні молекули. Вони потенційно можуть відновити ті системні ураження організму, які лежать в основі хроніки. Для цього необхідна адекватна і практично реально практично досягнута модель. У статті аналізується один з варіантів створення такої моделі. Як модельні тварин обрані миші, а в якості агента, що викликає системні ураження організму використовується CCl4. Наведений літературний аналіз показує, що, незважаючи на широко поширену думку про те, що ураження за рахунок CCl4 добре відпрацьовано, це далеко від дійсності. Кожен дослідник змінює схеми, а загальноприйнятою моделлю ураження CC14 є цироз печінки і тільки у щурів. Результати проведених авторами досліджень-ний дозволили розробити 
методику системного ураження організму мишей з використання CCl4. Наведено схему такої методики, дані іiі граничні умови і приведені вибіркові приклади, що показують наявність і характер системного ураження.

Ключ ов і сл ов а: CCl4, стовбурові клітини, системного ураження, модельний організм, клітинно-цитокиновая терапія.

\section{Модель системного поражения организма для разработки многоцелевой клеточно-цитокиновой терапии.}

В. А. Кордюм, Ю. Б.Чайковский, Д. М. Иродов, М. В. Драгулян, Т. П. Гулько, П. В. Бучек, А. В. Корсак, А. В. Неверовский.

В последние десятилетия основные патологии человека приняли, в своём большин-стве, хронический характер с множественными нарушениями. Сегодня биология и меди-цина вышли на принципиально новые возможности лечения. Наиболее перспективными в этом плане являются технологии, использующие стволовые клетки и сигнальные молеку-лы. Они потенциально могут восстановить те системные поражения организма, кото-рые лежат в основе хроники. Для этого необходима адекватная и практически реально практически достигнутая модель. В статье анализируется один из вариантов создания такой модели. В качестве модельных животных выбраны мыши, а в качестве агента, вызывающего системные поражения организма используется CC14. Приведенный лите-ратурный анализ показывает, что, несмотря на широко распространенное мнение о том, что поражения за счет CCl4 хорошо отработано, это далеко от действительно-сти. Каждый исследователь меняет схемы, а общепринятой моделью поражения CCl4 является цирроз печени и только у крыс. Результаты проведенных авторами исследова-ний позволили разработать методику системного поражения организма мышей с исполь-зованием CCl4 . Приведена схема такой методики, даны ее граничные условия и приведе-ны выборочные примеры, показывающие наличие и характер системного поражения.

Кл ючевы е сл о в: CC14, стволовые клетки, системного поражения, модельный организм, клеточно-цитокиновая терапия. 